\title{
Ballistic Opportunities' Evaluation of Artillery Projectile with a Rocket Ramjet
}

\author{
B.E. Kert ${ }^{1,3}$, V.A. Chubasov ${ }^{2}$, E.A. Znamensky ${ }^{1}$, V.O. Kravtsov ${ }^{1}$, \\ Y.O. Pavlov ${ }^{1}$, A.V. Panchenko', Y.V. Genkin ${ }^{4}$ \\ ${ }^{1}$ Baltic State Technical University "VOENMEH" named after D.F. Ustinov, \\ St. Petersburg, 190005, Russia \\ ${ }^{2}$ Mikhailovsky Military Artillery Academy, St. Petersburg, 195009, Russia \\ ${ }^{3}$ Societe with limited liability "Educational-scientific-production centre of computer technologies", \\ St. Petersburg, 190005, Russia \\ ${ }^{4}$ Joint stock company "Research and Production Association "Pribor", \\ Moscow, 117519, Russia \\ kert@,mail.ru
}

\begin{abstract}
Based on the analysis of existing technical solutions, promising structural designs of ammunition with rocket ramjet of 130, 152, and $203 \mathrm{~mm}$ caliber have been developed. Mathematical models of the ballistic functioning of artillery projectiles are implemented in software, which allow us to analyze the influence of design parameters on the ballistic functioning of active, active-reactive ammunition and ammunition with rocket ramjet. For ammunition of a promising scheme, a calculation was made of the support parameters and characteristic periods of the rocket ramjet, providing the possibility of increasing the firing range to $60 \mathrm{~km}$ or more.
\end{abstract}

Keywords: rocket ramjet, artillery projectile, constructive scheme, paste fuel.
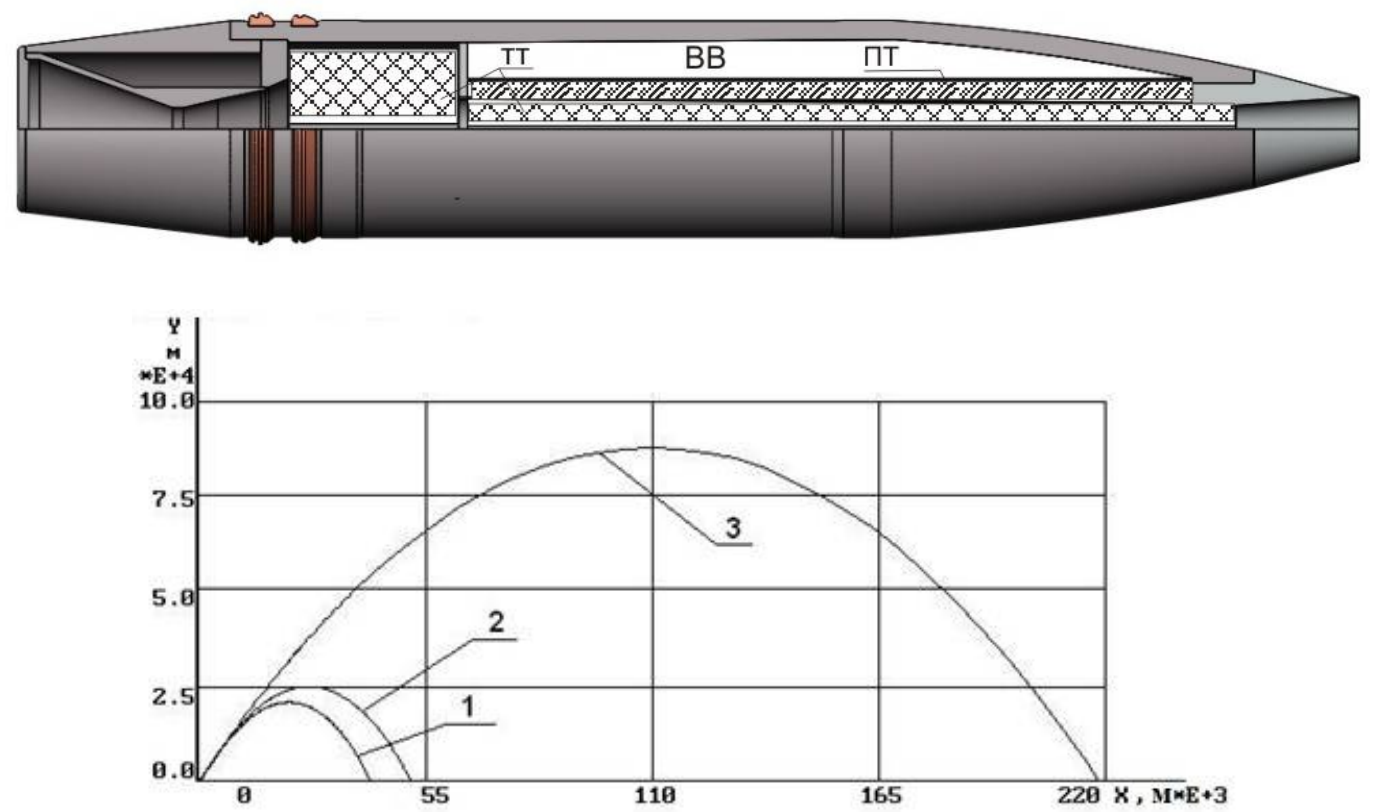

The carried out studies allow us to conclude that it is possible and advisable to develop long range projectiles equipped with an out-barrel dispersal system including rocket ramjet on paste fuel with or without solid propellant ramjet. 
УДК 358.111 .2

\title{
Оценка баллистических возможностей артиллерийских снарядов с ракетно-прямоточными двигателями
}

\author{
Б.Э. Кэрт ${ }^{1,3}$, В.А. Чубасов ${ }^{2}$, Е.А. Знаменский ${ }^{1}$, В.О. Кравцов ${ }^{1}$, \\ Я.О. Павлов ${ }^{1}$, А.В. Панченко ${ }^{1}$, Ю.В. Генкин ${ }^{4}$ \\ ${ }^{1}$ БГТУ «ВОЕНМЕХ» им. Д.Ф. Устинова, \\ Россия, г. Санкт-Петербург, 190005, 1-я Красноармейская ул., д. 1 \\ ${ }^{2}$ Михайловская военная артиллерийская академия, \\ Россия, г. Санкт-Петербург, 195009, ул. Комсомола, д. 22 \\ ${ }^{3}$ OОО «УНПЦ «КОМТЕХ», \\ Россия, г. Санкт-Петербург, 190005, 1-я Красноармейская ул., д. 1 \\ 4 АО "НПО "Прибор" Россия, г. Москва, 117519, Кировоградская ул., д. 1
}

kert@mail.ru

\begin{abstract}
Аннотация
На основе анализа существующих технических решений разработаны перспективные конструктивные схемы боеприпасов с ракетно-прямоточными двигателями (РПД) калибром 130, 152, 203 мм. Программно реализованы математические модели баллистического функционирования артиллерийских снарядов, позволяющие анализировать влияние конструктивных параметров на баллистическое функционирование активных, активно-реактивных боеприпасов и боеприпасов с РПД. Для боеприпасов перспективной схемы проведено расчетное обоснование опорных параметров и характерных периодов работы РПД, обеспечивающих возможность увеличения дальности стрельбы до 60 км и более.
\end{abstract}

Ключевые слова: ракетно-прямоточный двигатель, артиллерийский снаряд, конструктивная схема, пастообразное топливо.

\section{1. Введение}

Разработка снарядов ствольной артиллерии повышенной дальности, оснащенных устройствами доразгона на траектории, является перспективным направлением развития военной техники. При этом одним из наиболее перспективных направлений является использование ракетно-прямоточных двигателей (РПД) или комбинированных энергосиловых установок (КЭСУ), сочетающих встроенный РПД и ракетный двигатель на твердом (РДТТ) или пастообразном (РДПТ) топливе. Имеется достаточно обширная литература на тему моделирования и проектирования РПД, однако развитые математические модели, существенно использующие конструктивные параметры РПД и пригодные к использованию в системах машинного проектирования и оптимизации конструкций, отсутствуют. Технические реализации снарядов с РПД носят единичный опытный характер. Вопросы сочетания РПД и РДТТ (РДПТ) в рамках единой КЭСУ не прорабатывались. В настоящей работе предложена математическая модель баллистического функционирования снаряда с КЭСУ и на ее основе показана возможность реализации выстрелов на дистанции 60 и более км для типовых калибров артиллерийских снарядов. 


\section{2. О проблеме увеличения дальности}

Доминирующей тенденцией в развитии полевой артиллерии основных сил и ее боеприпасов является увеличение дальности стрельбы. Это обусловлено взглядами на современную военную операцию, как на процесс, протекающий на большом пространстве. Эти взгляды нашли свое отражение в военных доктринах США и НАТО [1], [2].

Увеличение дальности стрельбы достигалось сочетанием на новом уровне давно известных решений - увеличения длины ствола, объема зарядной каморы, разработки новых энергонасыщенных порохов с прогрессивным законом горения, улучшения аэродинамической формы снаряда. В дальнейшем к этому добавились такие способы, как использование донной выемки, установка донного газогенератора, снабжение снаряда РДТТ [3], [4]. В настоящий момент можно констатировать, что указанные способы достигли предела своих возможностей.

Увеличение начальной скорости снаряда требует разработки новых конструктивных схем выстрела. Перспективными способами повышения дальности являются увеличение или поддержание полетной скорости с помощью встроенных прямоточных воздушно-реактивных двигателей (ПВРД) и использование планирования при полете снаряда на пассивном участке [5], [6].

Использование ПВРД в артиллерийских снарядах было впервые предложено в патенте венгерского ученого Альберто Фоно в 1915 г [7]. В нашей стране идею применения ПВРД на твердом топливе (ПВРДТТ) в артиллерийском снаряде использовали Ю.А. Победоносцев и М.С. Кисенко [8]. Целью экспериментов была отработка ПВРДТТ для последующего использования в ракетной технике. В Германии под руководством В. Троммсдорфа в период с 1939 по 1943 гг. испытаны ряд конструкций снарядов с жидкостным ПВРД, которые достигали скоростей свыше 1500 м/с и дальностей до 200 км. Снаряды калибром 150 мм имели дульную скорость $1000 \mathrm{~m} / \mathrm{c}$, а за последующие 3.2 с разгонялись за счет ПВРД, использующего в качестве топлива сульфид углерода (CS2), до 1460 м/с. Также им были спроектированы снаряды для орудия калибра 280 мм с массой 170 кг, начальной скоростью 1223 м/с, наибольшей скоростью полета 1860 м/с и дальностью стрельбы около 350 км [9]. В 1976 году на базе НИМИ в лаборатории под руководством Б.М. Богданова начали проводиться исследования по созданию бронебойных подкалиберных снарядов с ПВРД [10]. Результаты работ вылились в создание нескольких макетных образцов боеприпасов.

На сегодняшний день интерес к созданию артиллерийских боеприпасов с ПВРД и ракетно-прямоточными двигателями (РПД) на твердом топливе подтверждается рядом полученных в последние годы отечественных патентов [11], [12], [13]. За рубежом также ведутся работы по созданию подобных боеприпасов. Так израильская фирма «Somchem» самостоятельно разрабатывает 155-мм активно-реактивный снаряд PRO-RAM с РПД, являющимся вариантом снаряда M2005 VLAP. По оценкам разработчиков, дальность стрельбы снарядом из орудия со стволом длиной 52 калибра составит не менее 70 км [3].

Требования к конструкции ПВРД и РПД для артиллерийских снарядов имеют ряд специфических особенностей, существенно отличных от таковых для крылатых ракет (КР). К ним относятся:

- $\quad$ необходимость выдерживания больших перегрузок в процессе выстрела, накладывающая существенные ограничения на конструкцию зарядов топлива;

- необходимость больших скоростей горения зарядов топлива, вызываемая кратковременностью процесса работы двигателя;

- $\quad$ необходимость работы на восходящем участке траектории с существенным изменением атмосферных условий вдоль траектории.

Разработка в последние годы высококалорийных пастообразных топливных составов делает возможной реализацию эффективных РПДПТ для артиллерийских снарядов [14], [15], $[16]$. 


\section{3. О конструктивных схемах артиллерийских снарядов с ПВРД и РПД}

Конструктивная схема артиллерийского снаряда с прямоточным воздушно-реактивным двигателем имеет свои особенности. В отличие от таковых для крылатых ракет, входной диффузор вряд ли может быть плоским и должен иметь круговое сечение. Кроме этого, проблемной является организация горения твердого горючего в потоке воздуха, доставляющего окислитель из входного диффузора (ВД). Легче реализовывать неполное сгорание твердого или пастообразного топлива во встроенном газогенераторе (ГГ) и его догорание в камере смешения и догорания (КСД) РПД. Толкающая схема двигателя предпочтительнее тянущей, так как в последней взаимодействие реактивной струи с обтекаемым ею корпусом снаряда снижает силу тяги. Близкое к донному срезу расположение кольцеобразного входного диффузора будет отрицательно влиять на работу двигателя из-за смены режима затекания, обусловленной нутационными колебаниями снаряда в полете. Наконец, для обеспечения полного догорания недоокисленных продуктов сгорания топлива в ГГ, необходима достаточно объемная и большая в длину КСД. Представленные в патентах [11]-[13] схемы снарядов удовлетворяют этим требованиям лишь частично. Более привлекательной представляется схема, представленная на рис. 1.

Схема позволяет так же использовать рабочие полости РПД - КСД и канал, связывающий ВД с КСД, для организации в них дополнительного РДТТ или РДПТ и превращения РПД в КЭСУ, включающую срабатывающий первоначально РДПТ, а затем, после освобождения рабочих полостей от топлива, включающийся в работу РПД. Вместо РДПТ в полости КСД может быть размещен присоединенный метательный заряд, срабатывающий в стволе при выстреле. Так может быть достигнуто повышение начальной скорости снаряда с одновременным снижением максимального давления в стволе.

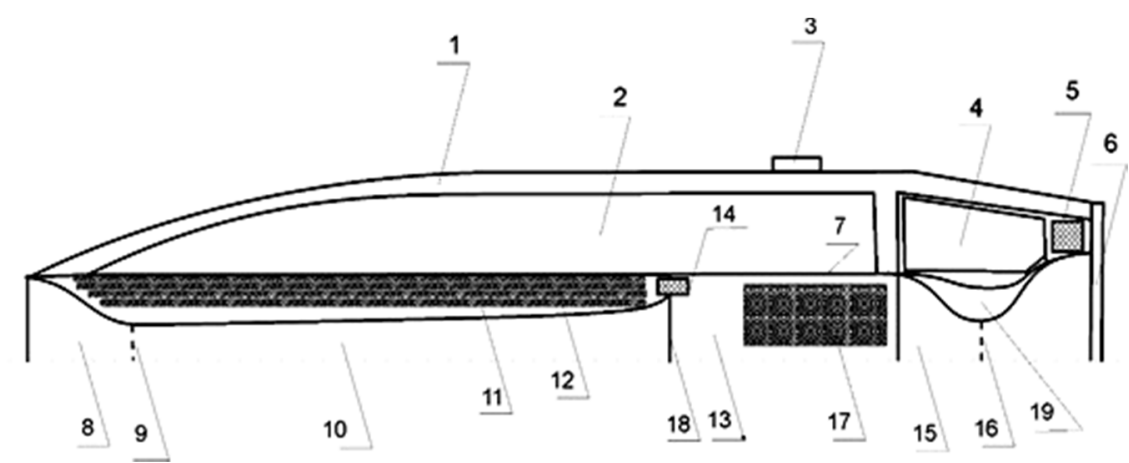

Рис. 1. Схема осколочно-фугасного снаряда с осевым расположением комбинированной ЭСУ, включающей РДПТ и РПД и диффузор с внутренним сжатием и трубчатым газогенератором:

1 - корпус; 2 - заряд ВВ; 3 - ведущий поясок; 4 - многофункциональный взрыватель с системой дистанционной инициации РПД; 5 - вышибной заряд опорного днища; 6 - опорное днище; 7 - корпус РПД; 8 - входной канал диффузора; 9 - критическое сечение диффузора; 10 - выходной канал диффузора; 11 - корпус газогенератора РПД; 12 - заряд газогенератора РПД; 13 - камера смешения и догорания РПД и камера сгорания РДПТ; 14 - воспламенительный заряд газогенератора; 15 - отстреливаемое сопло РДПТ и сопло РПД; 16 - критическое сечение сопла РДПТ; 17 - заряд РДПТ; 18 - разрушаемая заглушка сечений канала диффузора и сопла газогенератора

\section{4. Математическая модель баллистического функционирования снаряда с КЭСУ}

Будем полагать, что снаряд с КЭСУ, включающей встроенные разгонный РДТТ (РДПТ) и маршевый РПД, на различных этапах функционирования КЭСУ может рассматриваться или как снаряд с РДТТ или как снаряд с РПД. При этом уравнения движения центра масс 
снаряда с РДТТ и снаряда с РПД отличаются только способом расчета реактивной силы. Расчет реактивной силы в случае работы РДТТ представляет собой частный случай такового при работе РПД. Поэтому изложение математической модели баллистического функционирования на траектории снаряда переменной массы с встроенной КЭСУ, включающей РДТТ и РПД, проводим для снаряда с РПД. Будем также полагать, что снаряд представляет собой динамически и статически симметричное тело вращения, стабилизированное вращением или оперением.

В дополнение к допущениям основной задачи внешней баллистики (ОЗВБ) [17] будем полагать, что реактивная сила не зависит от угла нутации. Полагая стартовую систему отсчета, связанную с землей, инерциальной, следуя [18], запишем уравнение движения центра масс С снаряда с РПД как уравнение движения центра масс системы переменного состава с твердой оболочкой, пренебрегая Кориолисовыми силами инерции, вариационными силами и силами, обусловленными относительным движением центра масс снаряда. Тогда уравнение движения центра масс снаряда с РПД примет вид [14], [19], [20]

$$
m \cdot W_{c}=R+F, R=\left\{\left(\left(G_{B}+G_{T}\right) \cdot u_{s}-G_{B} \cdot V+P_{s}-P_{H}\right) \cdot F_{s}\right\} \cdot V^{0},
$$

где $R$ - сила тяги РПД; $G_{B}$ - расход воздуха на входе в диффузор; $G_{T}$ - расход продуктов сгорания заряда твердого топлива, поступающих в KCD РПД; $u_{s}$ - скорость газа в выходном сечении сопла относительно корпуса снаряда; $V$ - скорость центра масс снаряда; $P_{S}$ - давление в выходном сечении сопла; $P_{H}$ - атмосферное давление на текущей высоте; $F_{s}$ - площадь выходного сечения сопла; $V^{0}$ - орт, сонаправленный с вектором $V$ скорости центра снаряда; $F$ - главный вектор внешних сил, включающий силу тяжести и силу лобового сопротивления снаряда, представляемый в форме

$$
F=-m g \cdot y^{0}-\frac{1}{2} C_{x}(M) \rho S V \cdot V
$$

где $g$ - ускорение силы тяжести; $y^{0}$ - орт вертикальной оси стартовой системы координат; $C_{x}$ - коэффициент лобового сопротивления снаряда, как функция числа Маха М; $\rho$ - плотность воздуха на текущей высоте; $S$ - площадь миделя снаряда; $G_{B}=\rho V F_{d}$, где $F_{d}-$ площадь входного сечения диффузора. В частном случае работы только РДТТ забор воздуха через диффузор отсутствует и $G_{B}=0$.

Текущая масса снаряда с РПД определится из уравнения изменения массы снаряда, записанного при условии, что процесс течения рабочего тела в полости РПД носит квазистационарный характер

$$
\dot{m}=-G_{T}
$$

Для определения скорости $u_{s}$ и давления $P_{s}$ в выходном сечении сопла РПД. а также определения площади $F_{s}$ выходного сечения сопла с учетом возможного отрыва потока от стенок сопла, построена упрощенная термогазодинамическая модель рабочего процесса РПД, в основном соответствующая [14], [19], [20]. Ввиду громоздкости уравнений ниже приведена ее краткая характеристика.

Для реализации траекторных расчетов снарядов со встроенными РПД и/или РДТТ использовался пакет прикладных программ «МАТМЕХ» [21]-[22], предоставленный разработчиком - ООО «Учебно-научно-производственный центр компьютерных технологий». При реализации задачи в пакете «МАТМЕХ» были выполнены следующие модификации.

Введен в рассмотрение новый тип подвижного элемента (ПЭ) - "баллистический ПЭ точка переменной массы с тремя степенями свободы", имитирующий основную задачу внешней баллистики при правильном движении снаряда с встроенным РДТТ и/или РПДПТ. 
Для имитации процесса функционирования РПДПТ в систему введен новый типовой элемент - "сосуд известных параметров" нового типа, включающий входной диффузор, промежуточный газовод, камеру смешения и догорания (КСД) с соплом Лаваля. КСД может быть газодинамически связана с камерой сгорания пороха в газогенераторе (КСП). Предполагается, что параметры потока воздуха на входе в диффузор рассчитываются по скорости центра масс снаряда, а параметры атмосферы перед входом в диффузор и давление в атмосфере за выходным срезом сопла соответствуют атмосферным на высоте у.

В итоге, основная задача внешней баллистики снаряда с двумя встроенными двигателями (РДТТ и РПД) рассчитывается в ППП "МАТМЕХ" в ходе расчета функционирования газовой тепломеханической системы, полный граф газодинамических связей которой изображен на рис. 2.

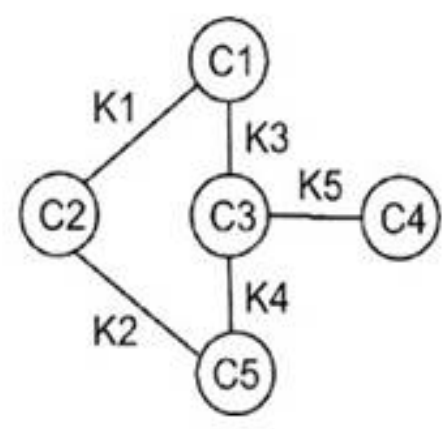

Рис. 2. Полный граф газодинамических связей расчета

Здесь С1 - сосуд известных параметров, задающий нормальные атмосферные условия; С2 сосуд газогенератор, имитирующий встроенный РДТТ; С3 - сосуд, имитирующий встроенный РПД; С4 - сосуд газогенератор, имитирующий КСП РПД; С5 - сосуд, имитирующий атмосферу, с движущимся в ней ПЭ; К2 - газодинамическая связь РДТТ с атмосферой через сопло Лаваля; К1, К3 - фиктивные связи, обеспечивающая сборку алгоритма расчета; К4 связь КСД РПД с атмосферой на высоте $y$ через сопло Лаваля; К5 - связь КСП с КСД РПД рассчитываемой системы.

Модель функционирования встроенного РПД включала: модель газогенератора (C4) (см. [21], [22]); модель проточного тракта РПД (С3), включающую трехскачковый входной диффузор с внутренним сжатием [19], выходной канал диффузора, течение в котором считалось одномерным, квазистационарным, а потерями на теплообмен и трение о стенки пренебрегалось; модель КСД с подводом недоокисленных продуктов сгорания (ПС) из газогенератора и воздуха из выходного канала диффузора с выходом через сопло Лаваля. Расчет догорания в КСД проводился в предположении, что КСД представляет собой эжектор, в котором происходит смешение двух параллельных струй - воздуха и ПС. Потерями на трение и теплообмен со стенками пренебрегалось. Параметры течения на входе в сопло определялись из законов сохранения массы, импульса и энергии (см. [19], [20]). Тепловой эффект реакции догорания и теплофизические свойства газа на входе в сопло определялись с учетом реального соотношения масс ПС и воздуха. При это полагалось, что размеры КСД достаточны для того, чтобы догорели все недоокисленные ПС, для догорания которых хватит воздуха. Течение в сопле Лаваля рассчитывалось с учетом возможности отрыва перерасширенного потока в работающем сопле. Сечение отрыва определялось из условия равенства давления за прямым скачком уплотнения в потоке наружному давлению. Если критическое давление на входе в сопло оказывалось меньше наружного атмосферного, то считалось что сопло не работает и в нем реализуется дозвуковое течение. 


\section{5. Предварительная конструктивная проработка изделий}

Как отмечено в [14], необходимо развитие научно-методического и инженерного обеспечения проектно-конструкторских работ в области РПД на твердых и пастообразных топливах. Даже ориентировочные расчеты по упрощенным методикам, подобным изложенной в разделе 4, требуют обоснованных сведений о возможных массогабаритных характеристиках (МГХ). Необходимо знать возможные к размещению на борту снаряда массы и объемы зарядов топлив, размеры и массы дополнительных элементов конструкции снаряда, реализующих бортовую ЭСУ. При этом снаряд должен нести боевую часть, по эффективности не уступающую таковым у существующих боеприпасов.

С использованием средств современного твердотельного 3D моделирования проведена конструктивная проработка некоторых вариантов реализации конструктивной схемы, представленной на рисунке 1, и так определены необходимые для численного исследования баллистического функционирования артиллерийских снарядов с КЭСУ конструктивные параметры. При этом прорабатывались только вопросы, связанные с рациональным размещением необходимых объемов элементов КЭСУ на борту снаряда и определялась толщина стенок конструкций, обеспечивающая необходимую прочность. Прочие элементы конструкции боеприпаса не детализировались. В качестве источника информации использовались данные [23]-[27].

Для конструктивной модификации были выбраны штатные боеприпасы 130-мм снаряд 3ОФ33, 152-мм снаряд 3ОФ45 и 203-мм снаряд 3ОФ43. На основе имеющейся информации по данным изделиям [23]-[27] созданы модели, адаптированные в пакетах SolidWorks и Компас-3D.

Их МГХ совпадали со штатными. После этого на их базе был разработаны 3D модели снарядов конструктивной схемы, представленной на рисунке 1 При этом для каждого снаряда реализовывались проектная модель типа 1, сохраняющая габариты прототипа, и модель типа 2 , сохраняющая массу дробящегося на осколки корпуса и взрывчатого вещества (BВ). На рисунке 3 изображена модель типа 2 для снаряда-прототипа 3ОФ43. Модели снарядов для прототипов ЗОФ33 и $3 О Ф 45$ аналогичны.

Предполагалось, что КСД и канал связи диффузора с КСД первоначально используются как камера сгорания разгонного РДТТ и в них размещаются трубчатые шашки ТТ. После их сгорания воспламеняется заряд ПТ в газогенераторе, горящий с торца, открывается канал связи диффузора с КСД, и так начинает работать маршевый РПДПТ. МГХ модельного снаряда составили: общая длина 1201.5 (995.5) мм, масса 137 (110) кг, масса ВВ 17.82 (17.8) кг, масса ПТ 4.22 (---) кг. В скобках указаны данные для прототипа. Толщины стенок трубчатого газогенератора выбирались исходя из рабочего давления в РДТТ и газогенераторе РПДПТ с коэффициентом запаса прочности 1.3 и исходя из продольной устойчивости оболочек при выстреле с коэффициентом запаса прочности 2.0.

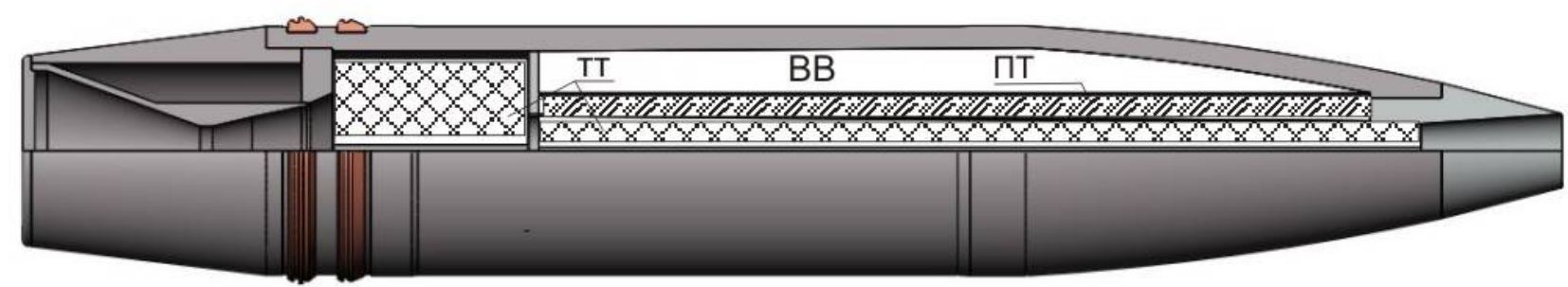

Рис. 3. Модельный снаряд калибра 203 мм 


\section{6. Расчет траектории модельных снарядов}

Моделировалось движение модельного 203 мм снаряда массой 137 кг, метаемого под углами близкими к $\theta_{0}=60^{\circ}$ с дульной скоростью $1000 \mathrm{M} / \mathrm{c}$. Метание активного снаряда постоянной массы позволило получить горизонтальную дальность $X=41392$ м (1). Метание снаряда с включением РДТТ на дульном срезе при комплектации РДТТ вышеописанными шашками суммарной массой 7.15 кг позволило получить горизонтальную дальность $X=51170$ м (2), то есть увеличило дальность на $23.6 \%$. в третьем случае РДТТ работал 1.3 с, после чего в момент времени $t=1.8$ с включался РПД, работавший $28 \mathrm{c}$, что позволило получить дальность $X=218490$ м при высоте траектории $Y=87963$ м (3). Расчетные траектории изображены на рис. 4.

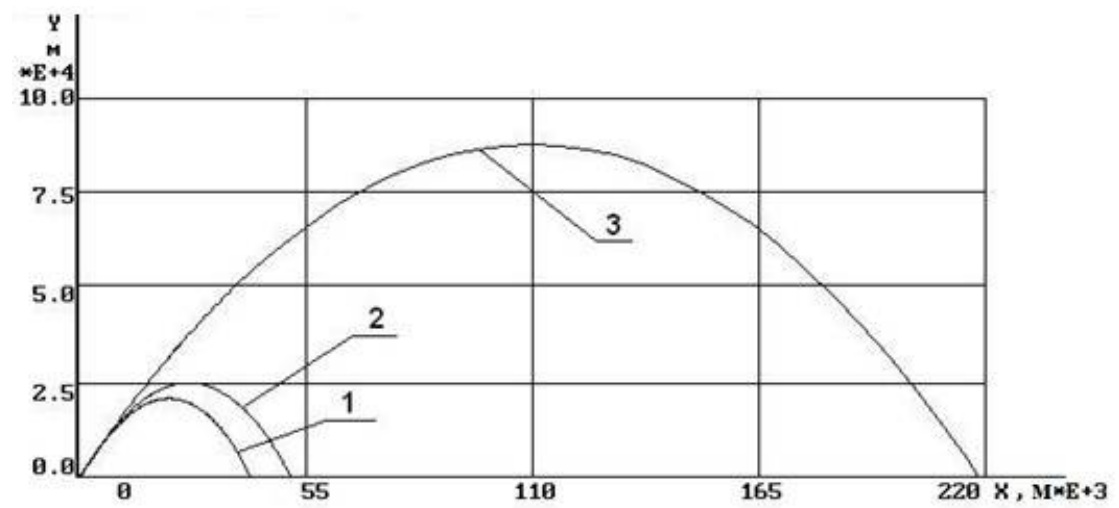

Рис. 4. Расчетные траектории модельного 203-мм снаряда

Причина столь существенного роста дальности пояснена на рис. 5, на котором изображены $Y$ - высота, $R E$ - реактивная сила, $V$ - скорость, $R x$ - сила лобового сопротивления.

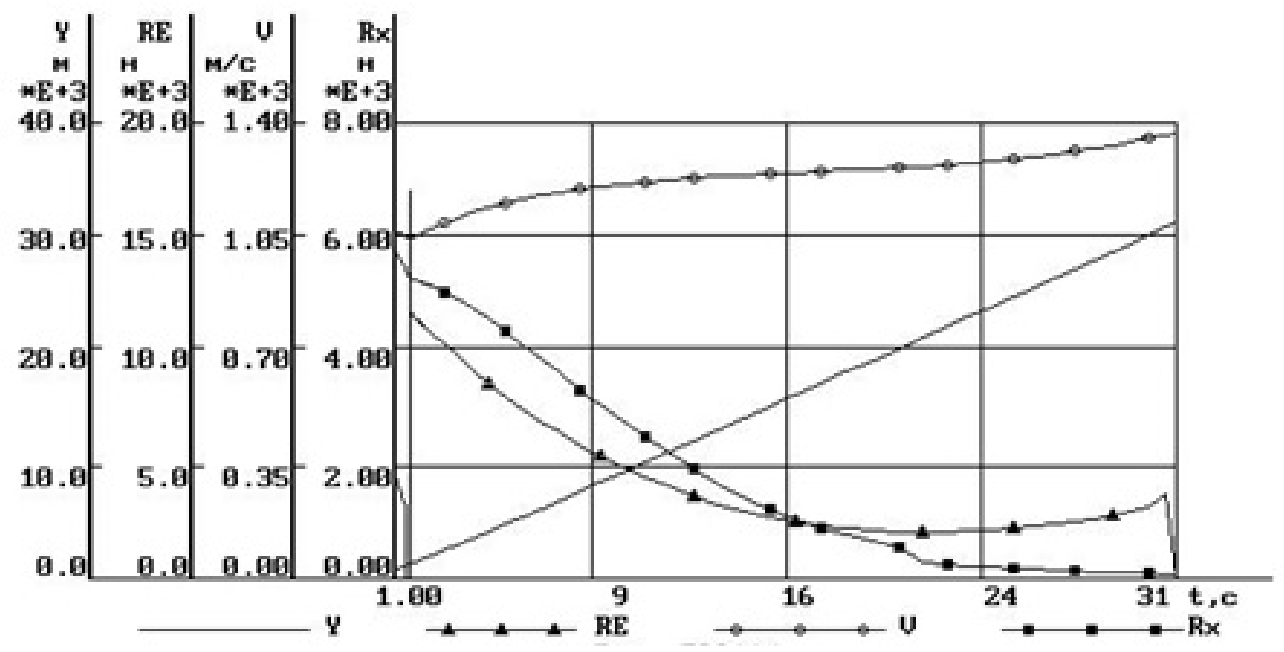

Рис. 5. Изменение характерных параметров при движении по траектории

Мощная двигательная установка как при работе РДТТ, так и при работе РПД развивает реактивную силу, в разы превышающую лобовое сопротивление. На 31 секунде полета снаряд разгоняется до скорости $1367.5 \mathrm{~m} / \mathrm{c}$ находясь на высоте 31344 м, то есть в верхних слоях стратосферы. Число Маха при этом доходит почти до 4.5. Аналогичные дальности для модельного снаряда калибром 130 мм составили соответственно 22232 м (1), 25507 м (2) и 114900 м (3). Для модельного снаряда калибром 152 мм соответственно 32292 м (1), 40320 м (2) и 70557 м (3). Отметим, что какая-либо оптимизация параметров снарядов не проводилась. 
Оценочные расчеты проведены исходя из допущения о полном догорании продуктов сгорания ПТ при смешении с воздухом в КСД в соответствии с реализуемым стехиометрическим соотношением, что само по себе проблематично. В этой связи планируется развитие построенной математической модели функционирования РПДПТ встраиванием в нее двух или трехмерной модели течения воздуха во ВД и осевом канале, в сочетании с моделью течения химически реагирующей смеси в КСД и сопле.

\section{7. Перспективное направление развития}

Предложения о разработке неуправляемых снарядов с дальностями стрельбы 100 и более км находят естественное возражение в том, что указанные снаряды будут иметь недопустимо высокий уровень технического рассеивания. В современных условиях необходимо иметь достаточно высокоточные боеприпасы, способные на больших расстояниях эффективно поражать компактные цели. Вопрос, однако, должен быть рассмотрен на базе критерия «цена-качество». Задача проектирования высокоточного активно-реактивного снаряда с дальностью действия более 100 км практически превращает его в дорогую ракету, запускаемую из артиллерийского ствола. Таковы разрабатываемые в США боеприпасы большого удлинения, стабилизируемые оперением, в которых существенно увеличен заряд топлива РДТТ. На сегодняшний день известно о двух прототипах [28-30], доведенных до опытных стрельб. Одним из них является управляемый 155-мм APC LRLAP (Long Range Land Attack Projectile), дальность стрельбы которого в ходе практических стрельб была на уровне $83 \div 116$ км, другим 127-мм ERGM (Extended Range Guided Munition), дальность которого также превышает 100 км. В то же время, можно указать очевидно целесообразное направление применения описанного нами подхода. Это разработка кассетных снарядов повышенной дальности.

В настоящий момент дальности стрельбы кассетными снарядами калибров 152 и 203 мм более чем вдвое ниже, чем таковые у соответствующих ОФС. Это обусловлено недостаточной прочностью кассетных снарядов, заставляющих уменьшать метательный заряд и снижать начальную скорость снаряда. Снабжение кассетного снаряда устройством силового внествольного доразгона в виде РПДПТ приведенной выше схемы способно купировать указанный недостаток, а требуемая кучность обеспечена путем снабжения снаряда системой импульсных двигателей коррекции. На рисунке 6 показан перспективный кассетный артиллерийский снаряд калибром 203 мм.

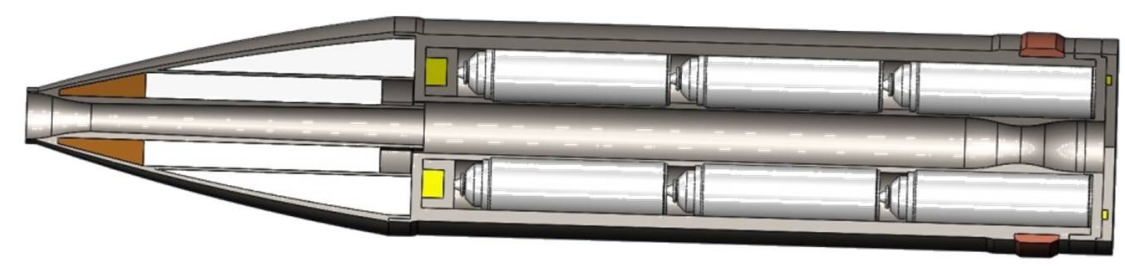

Рис. 6. Вариант кассетного артиллерийского снаряда калибром 203 мм

Приведенный снаряд по своим МГХ соответствует штатному 203-мм кассетному снаряду 3-О-14 «Склад» с осколочными боевыми элементами [31]. Расчетная дальность стрельбы составила около 70 км при 30 км у прототипа [26], [27].

\section{8. Заключение}

Проведенные исследования позволяют сделать вывод о возможности и целесообразности разработки снарядов повышенной дальности, снабженных системой внествольного доразгона, состоящей из КЭСУ, включающей сочетание РДТТ или РДПТ с РПДПТ, или включающей только РПДПТ. 
Целесообразную номенклатуру подобных снарядов необходимо определить постановкой соответствующих военно-научных исследований.

Очевидные сложности, связанные с большой величиной рассеивания, возникающие при стрельбе неуправляемыми снарядами на большие дальности, могут быть купированы при использовании средств коррекции снаряда на траектории, как импульсных, так и аэродинамических.

\section{Литература}

1. Douglas, W.S. Airland Battle Doctrine / W.S. Douglas.-Center For Naval Analyses, 1988.- 45 p.

2. Army Field Manual, FM 100-5, Operations, 1993.

3. Русинов В. Состояние и перспективы развития 155-мм боеприпасов полевой артиллерии за рубежом / В. Русинов // Зарубежное военное обозрение. - 2002 - № 3.- С. 24-29.

4. Зеленцов В.В. Перспективы развития боеприпасов дальнобойной морской артиллерии / В.В. Зеленцов, И.Е. Никитина, В.Е. Смирнов // Оборонная техника. - 2002 - № 11 - С. 9-14.

5. Реализация концепции повышения баллистической эффективности летательных аппаратов ближней зоны / В.В. Ветров [и др.] // Фундаментальные исследования. - 2012 - №11. - С. 377 382.

6. Thys, K. Leap Ahead-52 cal Artillery System/K. Thys // Presentation at the International Armaments Technology Symposium - 2004.

7. Szellemi Tulajdon Nemzeti Hivatala [Электронный pecypc] - Режим доступа: http://www.sztnh.gov.hu/feltalalok/fono.html (27.04.2015).

8. Меркулов И.А. Первые экспериментальные исследования прямоточных воздушно-реактивных двигателей ГИРДа / И.А. Меркулов // Из истории авиации и космонавтики. - 1965. - Вып. 3 C. 21-32.

9. Trommsdorff, W. High-velocity free-flying ramjet units (TR-Missiles) / W Trommsdorff // History of German guided missiles development: AGARD First Guided Missiles Seminar. - 1956.

10. Научно-исследовательский машиностроительный институт (НИМИ) страницы истории, события, люди (1932 - 2002 гг.) / под. ред. А.А. Калистова. - М., 2002.

11. Пат. RU 2493533, МПК F42/00. Активно-реактивный снаряд/ Алёшичева Л.И., Дунаев В.А., Никитин В.А. и др. Заявлено 29.05.2012; Патентообладатель ТулГУ.

12. Пат. RU 2486452, МПК F42B10/38. Способ увеличения дальности полета артиллерийского снаряда и устройство для его реализации/ Ветров В.В., Костяной Е.М. Заявлено 02.04.2012; Патентообладатель ТулГУ.

13. Пат. RU 2522699, МПК F42B15/00. Способ увеличения дальности полета артиллерийского снаряда/ Ветров В.В., Костяной Е.М., Дикшев А.И. Заявлено 10.12.2012; Патентообладатель ТулГУ.

14. Ракетно-прямоточные двигатели на твердых и пастообразных топливах / В.А.Сорокин [и др.]. - М. : Изд-во ФИЗМАТЛИТ. - 2010 - 320 с.

15. Патент №2637330 от 04.12.2017 по заявке №2016127295 от 07.07.2016. Способ приготовления коллоидной пасты. Павловец Г.Я., Мелешко В.Ю., Константинова М.А.

16. Павловец Г.Я., Мелешко В.Ю., Константинова М.А., Куликова Т.Л., Михайловская Л.А. Направления формирования пастообразных топлив для метательных зарядов артиллерийского выстрела // В сб. докладов Шестой Всероссийской НТК "Фундаментальные основы баллистического проектирования - 2018", 05 - 09 июня 2018 г., Санкт-Петербург, БГТУ «Военмех». 2018 C. $114-117$.

17. Дмитриевский А.А. Внешняя баллистика: Учебник для студентов Вузов / А.А. Дмитриевский, Л.И. Лысенко. - Изд. 4-е, перераб. и доп. - М. : Изд-во Машиностроение. - 2005 -608 с.

18. Динамика ракет: Учебник для студентов вузов / К.А. Абгарян [и др.]; под ред. В.П. Мишина. М. : Машиностроение. - 1990 - 464 с. 
19. Абрамович Г.Н. Прикладная газовая динамика. В 2 ч.: Учеб. руководство: Для втузов / Г.Н. Абрамович. - Изд. 5-е, перераб. и доп. - М. : Наука. - 1991 - Ч.1. - 600 с.

20. Орлов Б.В. Основы проектирования ракетно-прямоточных двигателей для беспилотных летательных аппаратов / Б.В. Орлов [и др.]. - М.: Машиностроение. - 1967 - 424 с.

21. К Кэрт Б.Э. Разделение неуправляемых снарядов систем залпового огня / РАРАН; Б.Э. Кэрт, В.И. Козлов, Н.А. Макаровец; под ред. Н.А. Макаровца. М.: Машиностроение, 2008438 с.: ил. (Справ. б-ка разработчика-исследователя).

22. Кэрт Б.Э. Математическое моделирование и экспериментальная отработка систем разделения реактивных снарядов в 2 ч. Часть 1.2: учеб. пособие для вузов / Б.Э. Кэрт, В.И. Козлов, Н.А. Макаровец. - 2-е изд., испр. и доп. - М.: Издательство Юрайт, 2018 - 240 с., 258 с. —(Серия: Авторский учебник).

23. Техническое описание и инструкция по эксплуатации 152-мм гаубицы 2А65 и 2С19. Часть 3 Боеприпасы. / Министерство обороны Российской Федерации, - М., 1999, 86 с.

24. Таблицы стрельбы для равнинных и горных условий 152-мм гаубицы 2А65 и 152-мм самоходной гаубицы 2С19. Часть 1 - 2-е изд. / Министерство обороны Российской федерации, 3-ий Центральный научно-исследовательский институт, М., 2005, 437 с.

25. 130-мм пушка М-46 и 152-мм пушка М-47. Руководство службы. - 3-е изд. / Ордена трудового красного знамени Военное издательство Министерства обороны СССР, М., 1968, 383 с.

26. Изделие 2С7. Техническое описание и инструкция по эксплуатации. Общие сведения. Книга 1 / Военное издательство, М., 1988, 104 с.

27. Бабушкин Ю. Оружие России. / Бабушкин Ю., Дегтярев А., Антипов Ю., Михайлов С., Слюнина Т. Издательский дом «Военный Парад», М., 2000, 824 с.

28. IHS Jane's Weapons Ammunition 2012-2013 (Jane's Weapon Systems Ammunition) by Leland S. Ness.

29. Конструкция, эксплуатация и основы проектирования артиллерийских орудий и боеприпасов. Часть 1. «Артиллерийские боеприпасы».- СПб.: МВАА, 2014. - 186 с.

30. Чубасов В.А. Направления развития дальнобойного ствольного оружия и боеприпасов в интересах ракетных войск и артиллерии. //Сборник научных трудов 53 Международной НПК МВАА - СПб.: МВАА, 2018.

31. Бочков А.П. Кассетные артиллерийские боеприпасы /А.П. Бочков. Учебное пособие. - Л: ВАА, 1992. $-20 \mathrm{c}$. 